\title{
Review of Against the Modern World: Traditionalism and the Secret Intellectual History of the Twentieth Century
}

By Mark Sedgwick, OUP, 2009.

\author{
Review by Alison Assiter* \\ Address \\ *Correspondence: [alison.assiter@UWE.ac.uk]
}

Mark Sedgwick's book, Against the Modern World, was published in 2009, but it is compulsive reading for commentary on the contemporary world, beset as it is with the rise of the traditional far right as well as far right religious fundamentalisms. The book spells out some intellectual influences on both traditions of thought.

Sedgwick provides a powerful and interesting history of 'traditionalism' a body of ideas stemming from the work of a philosopher, Guénon - who was working in the early $20^{\text {th }}$ century and whose work combined a very specific reading of Hinduism, reducing it to the Vedanta, with some insights from Marsilio Ficino. The latter was a medieval priest who combined Platonism and Christianity. He considered the revival of Plato in the $15^{\text {th }}$ century to be (in Sedgwick's words) a 'gift from God to provide philosophical arguments to support Christianity'. (Sedgwick, p. 23)

Like a number of contemporary thinkers, including Saba Mahmood, whose work we have reviewed in this journal, Guénon, according to Sedgwick, used the concept of 'inversion' to describe aspects of what he saw as the decline of the modern world. He critiqued the 'illusions' of reason, progress, and change. He wanted to avert what he saw as the 'extinction' of the west. The 'extinction' was to be avoided by 'receiving traditional teaching by the restoration of oriental doctrines so as to push 
the west towards the restoration of traditional civilisations'. (Sedgwick, p. 26)

Sedgwick's book discusses various attempts, over the course of the twentieth century, to put Guénon's project into action - to restore "traditional civilisation" to the west. Sedgwick traces the influence of 'traditionalist' ideas on European fascism and on the Islamic revolution in Iran, amongst other areas. He is careful to note that the influences of these various thinkers on particular political movements were not direct. However, he points to a number of connections between traditionalist thinkers and fascism. One such is a comment from Evola, an Italian follower of Guénon ${ }^{1}$ and an admirer of a crude re-reading of Nietzsche's superman which he called the 'absolute individual'. (ibid. p. 99) Evola wrote, in 1929, 'to the extent that Fascism follows and defends these traditional principles, in that measure we may consider ourselves Fascists. That is all'. Later he wrote suggesting a 'more radical, more intrepid Fascism, a really absolute Fascism, made of pure force inaccessible to compromise' (see Sedgwick, p.101). Although, according to Sedgwick, Evola was not well received either in Mussolini's or in Hitler's circles, nonetheless, a version of his ideas appeared in a speech delivered by Chancellor von Papen in 1934. Von Papen was subsequently forced to resign and his speech -writer was killed. Yet Evola continued to attempt to influence fascist thinking and Himmler at one point commissioned an investigation of his ideas. Furthermore, in 1942 Mussolini called Evola to a meeting, following a reading of his book Sinetesi di dottrina della razza. The latter, Mussolini believed, offered a way of aligning Italian and German racialisms. Moreover, in his text Revolt against the Modern World, Evola argued for a connection between 'jihad' in the sense of an 'inner' holy war and external 'jihad'. The latter is waging war against the 'infidel' and he suggests that the latter is linked to the former as the body is to the soul. (see, Evola, 1934, pp.118-120) 
Evola has been recently cited by Steve Bannon, who is a major intellectual influence on Donald Trump 2 . Aaron Gillette, in his book Racial Theories in Fascist Italy (Gillette, 2003), described Evola as 'one of the most influential fascist racists in Italian history'.

In his chapter on the Islamic world, Sedgwick notes the popularity of traditionalist work in Algeria and Morocco, amongst those opposed to the socialist 'ethos' of the Algerian regime in the 1960 's. In post revolutionary Iran, although Sedgwick argues that 'traditionalist' thinking played no part in the early years of the revolution, he suggests that there were many traditionalists in the universities, and one was close to the supreme leader. They played an active role in the purging of Iran's universities in the 1980's, through the council for Cultural Revolution.

In the final chapter of his carefully researched book, Sedgwick notes that Guénon's ideas, while not original, synthesise a number of elements in a somewhat unusual way. One of the themes for which he became known is the view that 'wisdom' originates somewhere in the east, as opposed to the west. Hinduism and Perennialism (represented by Ficino) were the specific ingredients of Guénon's philosophical outlook, but other traditionalists deployed elements from Sufism and Taoism. Sedgwick argues that 'traditionalism' has something in common with 'Orientalism' as developed by Said. It is, Sedgwick suggests, the other side of the coin of Orientalism. Said showed how much western understanding of 'the east' owed more to the self-understanding of the west than to anything that actually existed. Traditionalism, Sedgwick argues, is the counterpoint of Orientalism. It is the inverse of Orientalism in that while Orientalism downplays the east, traditionalism, drawing on the same somewhat mythical idea of the East, applauds the latter but in a crude and simple way. He writes: 'Traditionalism contrasts a West characterised by modernity, materialism and mere technical skills to a Middle East of tradition, spirituality and wisdom. This understanding of the East is 
arguably no more accurate than that of the classic Orientalist'. (Sedgwick, p.266) As we have argued elsewhere in Feminist Dissent, crude dualisms like this undermine both east and west.

Guénon's final years were spent in Egypt where he developed his ideas, through practising as a Muslim, on the need to put theory into practice. Evola, as we have seen, saw practice in a rather different way.

Sedgwick suggests that there were many who might be described as 'traditionalists' who did not adopt any of the dubious political ideas outlined above. But, he notes: 'the entire field of contemporary religious studies (of which he himself is part) bears the imprint of Eliade's (another follower of some of the aspects of the above thought) 'soft traditionalism' and 'many leading scholars have been traditionalists'. (ibid. p.271) Sedgwick also suggests that many of the critics of traditionalism, including the original referee of Guénon's PhD, who failed it, have not treated them as serious scholars. He suggests, also, that their work has much in common with post-modernism, in their respective rejections of modernist ideas of 'science, rationalism and objectivity'. (ibid. p.264) However, maybe we need to take the ideas seriously if we are to understand something of the increasing influence of far-right thinking in today's world. We have drawn attention, in Feminist Dissent, to the post-modern rejection of these ideals. This book provides useful reading for those interested in these topics.

\section{References}

Aaron Gillette (2003) Racial Theories in Fascist Italy, London, Routledge.

Evola, J. (1932) Revolt against the Modern World, Rivolta cotra il mondo moderno, Milan: Hoepli. 


\section{Notes}

${ }^{1}$ Some commentators have challenged the link between Guenon and Evola. But he himself, in an interview in 2007, accepted the influence of the former on his work (see, http://www.gornahoor.net/?p=21).

${ }^{2}$ See: https://qz.com/909323/bannons-interest-for-julius-evola-unveils-the-sexism-atthe-core-of-trump/

\section{To cite this article:}

Assiter, A. (2018). Review of Against the Modern World: Traditionalism and the Secret Intellectual History of the Twentieth Century By Mark Sedgwick. Feminist Dissent, (3), 252-256. Retrieved from:

https://journals.warwick.ac.uk/index.php/feministdissent/index 